\title{
Covid-19 E Perfis De "Denúncias" Na Quarentena": As Implicações Do Uso De Dados Pessoais Para Expor Quem Descumpre As Regras De Isolamento Social E A (In)Violabilidade Do Direito À Extimidade
}

\author{
Eduarda Aparecida Santos Golart * \\ Universidade Federal de Santa Maria, Programa de Pós-Graduação em Direitos Emergentes na \\ Sociedade Global, Santa Maria-RS, Brasil. \\ (i) https://orcid.org/0000-0002-7491-3932 \\ Gabriela Gonçalves de Medeiros ** \\ Universidade Federal de Santa Maria, Programa de Pós-Graduação em Direitos Emergentes na \\ Sociedade Global, Santa Maria-RS, Brasil. \\ (i) https://orcid.org/o000-0001-9998-0835 \\ Isabel Christine Silva De Gregori *** \\ Universidade Federal de Santa Maria, Programa de Pós-Graduação em Direitos Emergentes na \\ Sociedade Global, Santa Maria-RS, Brasil. \\ (iD) https://orcid.org/0000-0002-3251-946X
}

Resumo: Contemporaneamente, presencia-se a cultura da visibilidade na qual o dia-a-dia e questões da vida privada passam a ser voluntariamente expostas nas redes sociais. Diante disso, surge o direito à extimidade como a prerrogativa que tem o titular de expor a intimidade em meios de sociabilidade- tal como as redes sociaise mesmo assim ter a possibilidade de estar protegido diante de atos de terceiros. Em razão disso, importa verificar a criação de perfis na rede social Instagram para "denunciar" pessoas que descumprem as medidas de isolamento social, impostas em decorrência do COVID-19, através da publicação de imagens retiradas dos perfis dos titulares das imagens publicizadas. Tendo em vista esses fatos, o problema que se apresenta neste trabalho é em que medida o uso de dados pessoais publicados em perfis do Instagram destinados a "denunciar" quem descumpre as regras de isolamento social em tempos de COVID-19 gera violação do direito à extimidade? Para responder ao problema utiliza-se como método de abordagem o indutivo, como método de procedimento a análise bibliográfica e por fim, o uso de fichamentos e resumos enquanto técnica de pesquisa. Assim, conclui-se que há a violabilidade do direito à extimidade nos casos em análise, pois em que pese às fotos tenham sido postadas na rede social Instagram, isso não as torna domínio público e tampouco autoriza o seu uso indiscriminado por terceiros.

Palavras-chave: COVID-19. Direito à extimidade. Sociedade em rede.

* Mestranda no Programa de Pós-Graduação em Direitos Emergentes na Sociedade Global (UFSM). Email: eduardaparecida@hotmail.com

** Mestranda no Programa de Pós-Graduação em Direitos Emergentes na Sociedade Global (UFSM). Email: gabyi.medeiros@hotmail.com

*** Doutora em Desenvolvimento Regional pela Universidade de Santa Cruz do Sul. Professora do Programa de Pós- Graduação Stricto Sensu da Universidade Federal de Santa Maria (UFSM). E-mail: isabelcsdg@gmail.com

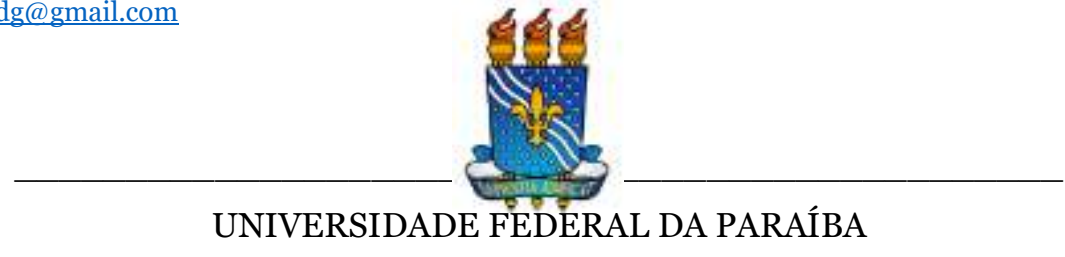

Programa de Pós-Graduação em Ciências Jurídicas

DOI: https://doi.org/10.22478/ufpb.1678-2593.2020v19n42.54299 


\title{
Covid-19 E Perfis De "Denúncias" Na Quarentena": As Implicações Do Uso De Dados Pessoais Para Expor Quem Descumpre As Regras De Isolamento Social E A (In)Violabilidade Do Direito À Extimidade
}

\author{
Eduarda Aparecida Santos Golart ${ }^{1}$
}

Gabriela Gonçalves de Medeiros

Isabel Christine Silva De Gregori

\section{INTRODUÇÃO}

A atual estrutura social encontra-se baseada no uso massivo da Internet e das redes sociais, que acabam por trazer efeitos tanto jurídicos, como sociais e culturais. No que tange a esses efeitos, podese considerar que há uma cultura da visibilidade na qual, cada vez mais, as rotinas de trabalho, lazer e diversas outras atividades estão sendo mostradas nas redes. Diante dessa visibilidade, não há como continuar com um modelo tradicional de privacidade que apenas tutela aquilo que está escondido e resguardado dos olhos de terceiros.

Sendo assim, é preciso falar sobre direito à extimidade, que nada mais é do que uma nova interpretação ao direito à privacidade $\mathrm{e}$ intimidade. Com base nesse novo direito implícito, o titular tem a possibilidade de usufruir de forma positiva da intimidade, ou seja, a prerrogativa de apresentar questões da sua vida privada a terceiros,

${ }^{1} \mathrm{O}$ presente trabalho foi realizado com apoio da Coordenação de Aperfeiçoamento de Pessoal de Nível Superior - Brasil (CAPES) - Código de Financiamento oo1. 
com o intuito de receber aprovação e feedbacks importantes para a construção da identidade do titular, sem que com isso esteja desprotegido juridicamente.

Essas informações que são expostas no ciberespaço, referem-se a dados pessoais. Acontece que, após a publicação, terceiros podem utilizá-los, muitas vezes sem o consentimento do titular e sem observar direitos fundamentais conexos.

Diante da questão, pretende-se discutir a criação de diversos perfis na rede social Instagram que têm por objetivo expor e "denunciar" pessoas que estão descumprindo as regras de isolamento social impostas no período de pandemia do Covid-19. Para isso, os administradores dos referidos perfis publicam imagens extraídas de contas pessoais de outros usuários - referentes a momentos que estes estão descumprindo ou "furando" o isolamento social e republicam no perfil "denunciante".

Tendo por base esses fatos, cabe questionar em que medida o uso de dados pessoais publicados em perfis destinados a "denunciar" quem descumpre as regras de isolamento social em tempos de COVID19 gera violação do direito à extimidade.

Para a análise proposta, a pesquisa se utilizou de três contas do Instagram e, em cada perfil, fez o recorte de três publicações elegidas. O critério de escolha dos perfis que serão analisados se deu a partir do número de seguidores da conta e da necessidade da mesma ser aberta, ou seja, acessível a todos os usuários do Instagram. Portanto, optouse por contas que são abertas e que contavam com mais de três postagens, tendo em vista que se analisará 3 postagens de cada perfil selecionado. Por fim, observou-se ainda o número de seguidores das contas, de modo a selecionar um perfil de até mil seguidores, um de até 10 mil seguidores e outro acima de $10 \mathrm{mil}$, a fim de observar o comportamento de diferentes perfis e com diferentes números possíveis de acesso.

Outro critério utilizado relaciona-se com a delimitação das publicações, já que haviam inúmeras postagens em cada conta selecionada. Assim, buscou-se imagens em que se compreendeu estar 
evidenciado que foram postadas originariamente de forma voluntária pelo usuário titular das imagens e posteriormente republicadas pela página "denunciante".

Após a descrição de como se deu a escolha dos perfis e das publicações, passa-se a análise dos métodos de abordagem, procedimento e técnica. Como método de abordagem emprega-se o indutivo, tendo em vista que se parte de uma verificação dos perfis e das publicações selecionadas para, posteriormente, estudar o direito à extimidade e sua possível violação diante das publicações das contas do Instagram analisadas. Para o procedimento, adequa-se a análise bibliográfica, através do uso de livros, revistas e artigos científicos relativos à temática trabalhada. Por fim, a técnica aplicada é a elaboração de resumos e fichamentos a fim de melhor organizar e utilizar no presente trabalho.

O tema em estudo justifica-se principalmente em razão da sua atualidade, uma vez que esses acontecimentos estão ocorrendo durante a pandemia do COVID-19, sendo este um momento histórico e com surgimento de fatos novos no Brasil e no mundo, com diversos efeitos jurídicos, em que não há uma discussão consolidada. Além disto são situações que acabam por repercutir diretamente na vida dos envolvidos merecendo, por isso, a atenção por parte do Direito e da pesquisa científica. Dessa forma, o presente trabalho possui como objetivo o de atualização bibliográfica frente à comunidade acadêmica.

O trabalho foi dividido em dois capítulos. O primeiro deles cuidou de estudar a sociedade em rede enquanto propulsora do uso das plataformas digitais, bem como apresentar os perfis e as respectivas publicações selecionadas. $\mathrm{O}$ segundo capítulo investiga o direito à extimidade e verifica a sua possível violação diante das publicações apresentadas no capítulo antecedente. 


\section{A SOCIEDADE EM REDE E A CRIAÇÃO DE PERFIS NO INSTAGRAM PARA EXPOR PESSOAS QUE DESCUMPREM AS MEDIDAS DE ISOLAMENTO SOCIAL IMPOSTAS EM RAZÃO DA PANDEMIA DO COVID-19}

A Revolução Industrial, iniciada na Inglaterra no século XVIII, difundiu-se no mundo inteiro, desencadeando uma série de transformações e trazendo um novo paradigma tecnológico, organizado com base na tecnologia da informação (CASTELLS, 1999, p. 25). Em razão disso, na década de 70, a Internet transformou o processo de comunicação entre a sociedade a partir das redes digitais, apoiadas pela microeletrônica, acarretando uma mudança no comportamento dos indivíduos dessa sociedade (CARDOSO, 2007, p. 09).

A revolução tecnológica se concentra nas tecnologias da informação e altera rapidamente a base material da sociedade. Em decorrência desses avanços tecnológicos, a sociedade contemporânea se transforma na denominada sociedade em rede (CASTELLS, 1999, p. 21). Para Castells, a sociedade em rede é caracterizada pela predominância da forma organizacional.

As redes de comunicação digital são a "coluna vertebral da sociedade em rede". Diante disso, as redes de comunicação interligamse com essa sociedade em rede na medida em que os usuários se tornam produtores da tecnologia, demonstrando a força da Internet, em razão da sua arquitetura (CASTELLS, 2005, p.18- 28). Portanto, os usuários são os principais produtores dessa rede, moldando-se a ela e também a modificando.

Essa articulação em rede ocorre devido ao sistema de mídias e está relacionada com as dimensões de interação que a tecnologia possibilita, bem como pela valorização social das possibilidades de interação. Dessa forma, surge o ciberespaço, o "lugar" em que essas interações ocorrem. O ciberespaço seria “o espaço de comunicação aberto pela interconexão mundial dos computadores e das memórias 
dos computadores, definição que engloba o conjunto dos sistemas de comunicação eletrônicos [...]" (LEONARDI, 2012, p. 127).

Em virtude disso, nesse "local" compreendido como ciberespaço há uma transmissão de informações decorrente dessa interconexão com os sistemas eletrônicos. Pierre Lévy conceitua o ciberespaço como sendo "o espaço de comunicação aberto pela interconexão mundial dos computadores e das memórias dos computadores" (LÉVY, 1999, p. 92, grifo no original). Para o referido autor, essa definição inclui o conjunto de sistemas de comunicação eletrônicos, tendo em vista que estes transmitem informações provenientes do meio digital.

Leonardi (2012, p. 128) refere que alguns doutrinadores distinguem ciberespaço e Internet, pois entendem que a Internet representaria a infraestrutura física das telecomunicações, por representar a rede internacional de computadores conectados entre si. Já o ciberespaço seria o "lugar" dessa comunicação, criado a partir da utilização da infraestrutura física que seria a Internet.

Portanto, a Internet seria um marco do ciberespaço e máquina propulsora da sociedade em rede. Em razão disso, tem-se que o ciberespaço proporciona a interação de pessoas em qualquer lugar do mundo através dessa rede de computadores denominada Internet, que, por sua vez, proporciona os protocolos de comunicação de dados usados no ciberespaço.

Diante do exposto desenvolve-se uma cultura da era da informação, caracterizada pela possibilidade dos próprios usuários consumirem conteúdos de acordo com suas necessidades culturais, de maneira autônoma e com diversas possibilidades de interação, gerando um "capital simbólico para o exercício de influência sobre as indústrias de produção cultural e sobre a sociedade em geral" (CARDOSO, 2007, p. 27).

Em decorrência dessa expansão das redes de comunicação e da difusão em massa da Internet, há uma supervalorização de outras formas de interatividade - como as redes sociais - em que os usuários 
se tornam receptores e produtores de conteúdo e de informação (VAZ, 2015, p. 35). Para Raquel Recuero (2009, p. 102-103), os sites de redes sociais não se confundem com as redes sociais em si. Nesse sentido, sites de redes sociais foram definidos como sistemas que permitem: "i) a construção de uma persona através de um perfil ou página pessoal; ii) a interação através de comentários; e iii) a exposição pública da rede social de cada ator".

Os sites de redes sociais atuam tão somente como suporte para as interações que ocorrem dentro das redes sociais, sendo meramente um sistema que possibilita essa interação. Nesse sentido, o Instagram é um exemplo desses sites de redes sociais que proporciona essa interação de rede social. Se "a Internet constitui o grande oceano do novo planeta informacional, é preciso não esquecer dos muitos rios que a alimentam" (LÉVY, 1999, p. 126). Entende-se que o Instagram seria um desses rios que alimentam o grande oceano que é a Internet.

O Instagram é um aplicativo em que os usuários compartilham em seus perfis fotos e vídeos, com a opção de curtidas e comentários pelos demais usuários da plataforma. O referido aplicativo é utilizado por usuários do mundo inteiro como plataforma de compartilhamento desses conteúdos e também como instrumento de trabalho pelos influenciadores digitais que divulgam marcas e produtos em seus perfis. Para tornar-se um usuário do Instagram, é necessário instalar o aplicativo, que é compatível com diversos dispositivos eletrônicos e criar um perfil, inserindo dados pessoais, de forma gratuita ${ }^{2}$.

Em face dessa difusão da Internet e dos meios de interação, podemos identificar impactos intrinsicamente ligados à situação atual de pandemia mundial do COVID-19.

Em 11 de março de 2020 a Organização Mundial da Saúde (OMS) declarou o COVID-19 como pandemia, tendo em vista que o número de casos da doença fora da China aumentou 13 vezes, inclusive com os primeiros registros de óbitos no Brasil (CASCELLA; RAJNIK;

\footnotetext{
2 Diz-se gratuita, pois se entende que o pagamento pelo acesso à programas $\mathrm{e}$ conteúdo na internet não ocorre com pecúnia, mas sim através da captação dos dados pessoais dos usuários (BIONI, 2019, p. 47).
} 
Covid-19 E Perfis De "Denúncias" Na Quarentena": As Implicações Do Uso De...

CUOMO; DULEBOHN; DI NAPOLI, 2020, sp.). No Brasil, seguindo recomendações da Organização Mundial da Saúde (OMS), diversos estados e municípios decretaram, por um período de tempo, medidas de isolamento social, em razão das quais as pessoas deveriam permanecer dentro de suas casas -em quarentena- para evitar a propagação do Coronavírus.

Um mapeamento divulgado pelo portal de notícias do G1 (2020, p. 01) demonstrou que houve um aumento do consumo de mídia online no Brasil durante o período de quarentena. Corroborado a isso, de acordo com dados do Brasil Internet Exchange3, o consumo de internet aumentou 20\% no Brasil desde o início da quarentena (LAVADO, 2020, p. 01).

Esse aumento no consumo de Internet corroborou positivamente em diversos aspectos durante a pandemia do COVID19, possibilitando para algumas pessoas o trabalho home office, aulas on-line, cursos gratuitos e uma série de lives gratuitas realizadas por artistas e também por profissionais das mais diversas áreas de conhecimento para incentivar que as pessoas permanecessem em casa. Além disso, as redes sociais possibilitam uma interação com pessoas que estavam isoladas longe de seus familiares e amigos.

No entanto, em que pese os aspectos positivos propiciados pela Internet e pelas redes sociais no referido contexto, compreende-se também a manifestação de um cenário que propiciou a criação de perfis no Instagram direcionados exclusivamente a expor e a “denunciar" as pessoas que estivessem descumprindo as medidas de isolamento social, publicizando fotos e vídeos que os próprios usuários postavam em seus perfis pessoais - na maioria das vezes em seus stories ${ }^{4}$. Nesse sentido, grande parte das imagens publicadas pelos perfis de denunciação são prints - captura da imagem que está na tela - dos stories dos usuários expostos.

3O IX.br é um projeto do Comitê Gestor da Internet no Brasil que promove infraestrutura dos Ponto de Intercâmbio de Internet.

4 Recurso disponibilizado pelo Instagram, em que imagens e vídeos permanecem no perfil do usuário pelo período de 24 horas. 
Com sua atuação, os referidos perfis apresentaram-se com o intuito de promover constrangimento e represália dos usuários expostos por sua conduta, fazendo isto sem qualquer controle do alcance e proporção da divulgação dessas mídias, o que se pode compreender utilizando-se como exemplo o perfil "denunciante" denominado@vacilocovidbh, que atingiu a marca de 50 mil seguidores em apenas três dias (RAMOS; LANZA, 2020, p. 01).

Como forma de analisar os referidos perfis de exposição, houve o recorte de três perfis ainda ativos e de contas públicas, isto é, perfis em que qualquer pessoa pode acessar, sem precisar segui-los. Dessa maneira, as autoras captaram as publicações que serão analisadas posteriormente. A fim de preservar os usuários expostos, as autoras optaram em desfocar as imagens. O primeiro perfil analisado é denominado de “@furaquarentena8”, do qual se extraiu a captura de tela, apresentada na Figura 1, abaixo:

Figura 1: Captura de tela da página principal do perfil da rede social Instagram @furaquarentena8.

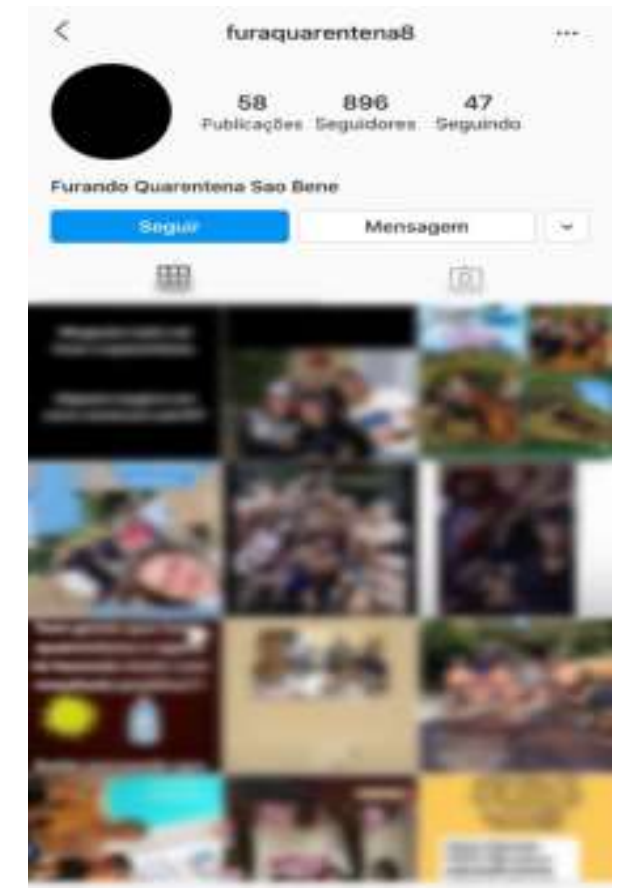

Fonte: Instagram @furaquarentena8.

Em sua primeira postagem, o perfil menciona que: "esse perfil foi criado pra você que não aguenta ver pessoas sem noção, furando 
Covid-19 E Perfis De "Denúncias" Na Quarentena": As Implicações Do Uso De...

a quarentena"s. Denota-se da sua descrição que o perfil foi criado exclusivamente para expor os indivíduos que descumprem as medidas do isolamento social. Na data de acesso de 18 de agosto de 2020, o perfil contava com 896 seguidores e 58 publicações.

Figura 2: foto postada pelo perfil @furaquarentena8 em 21 de junho de 2020.

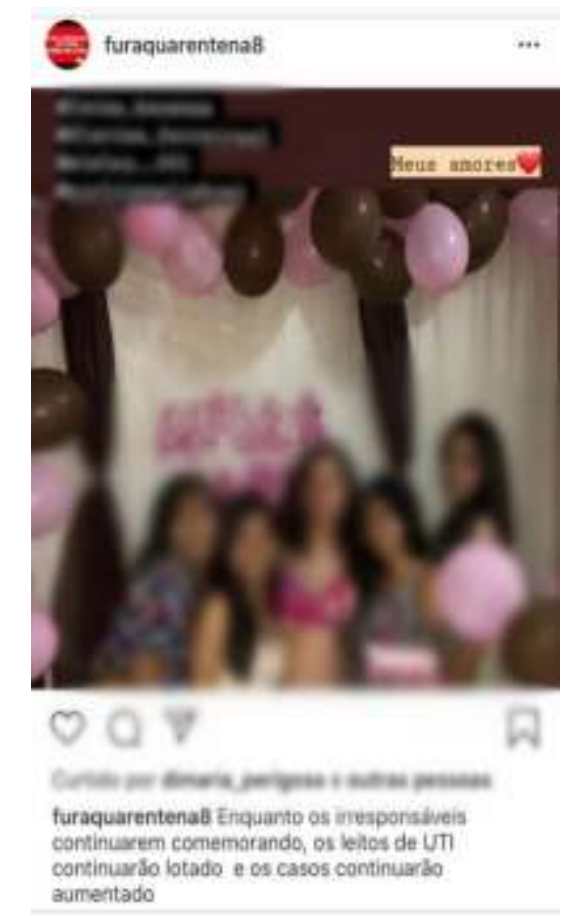

Fonte: Instagram @furaquarentena8.

Na imagem, cinco meninas participam de um chá de bebê e todas elas são marcadas na foto. A legenda da foto é a seguinte: "enquanto os irresponsáveis continuarem comemorando, os leitos de UTI continuarão lotado (sic.) e os casos continuarão aumentando", demonstrando o caráter repressivo do perfil.

Figura 3: foto postada pelo perfil @furaquarentena8 em 21 de junho de 2020.

5INSTAGRAM. @furaquarentena8. 2020. Disponível em: https://www.instagram.com/furaquarentena8/?hl=pt-br. Acesso em: 28 jun.2020. 


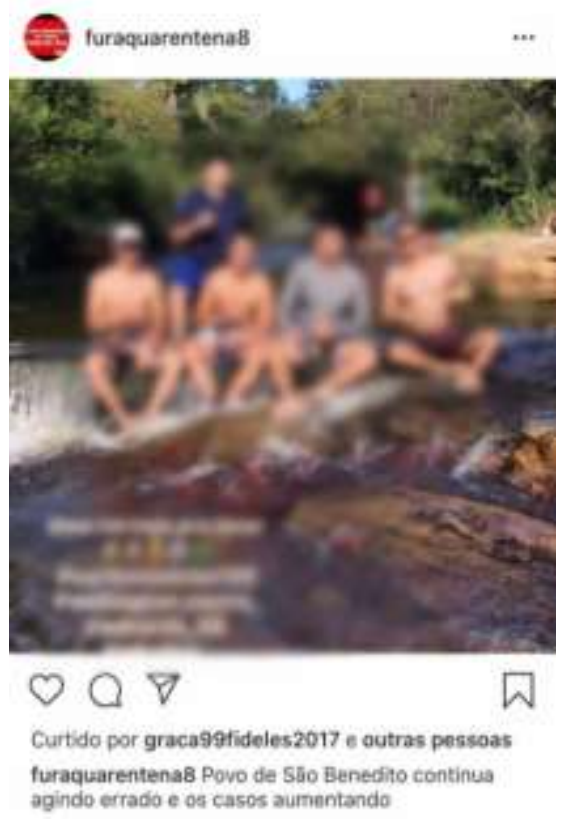

Fonte: Instagram @furaquarentena8.

Na imagem, alguns homens aparecem em uma cachoeira e são marcados na foto. A legenda da imagem é a seguinte: "Povo de São Benedito continua agindo errado e os casos aumentando".

O segundo perfil que será analisado, “@vaciloscvd_ac” descreve em sua biografia que "se você conhece alguém que está furando a quarentena aqui no Acre, mande no nosso Direct. Se não for por bem, vai ser por mal \#todoscontracovid19", conforme se pode ver na Figura 4:

Figura 4: Captura de tela da página principal do perfil da rede social Instagram @vaciloscvd_ac 
Covid-19 E Perfis De "Denúncias" Na Quarentena": As Implicações Do Uso De...

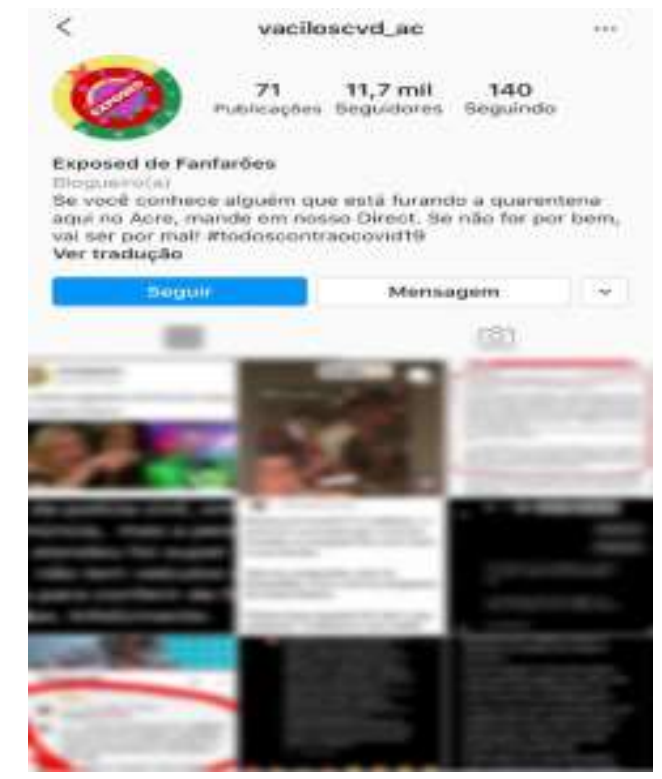

Fonte: Instagram @vaciloscvd_ac.

Na data de acesso de 18 de agosto de 2020, o perfil contava com 11,7 mil seguidores e 71 publicações, diante disso, demonstra-se que o perfil também foi criado com o intuito de denunciar os usuários que descumprem as medidas de isolamento social.

Figura 5: foto postada pelo perfil @vaciloscvd_ac em 20 de abril de 2020.

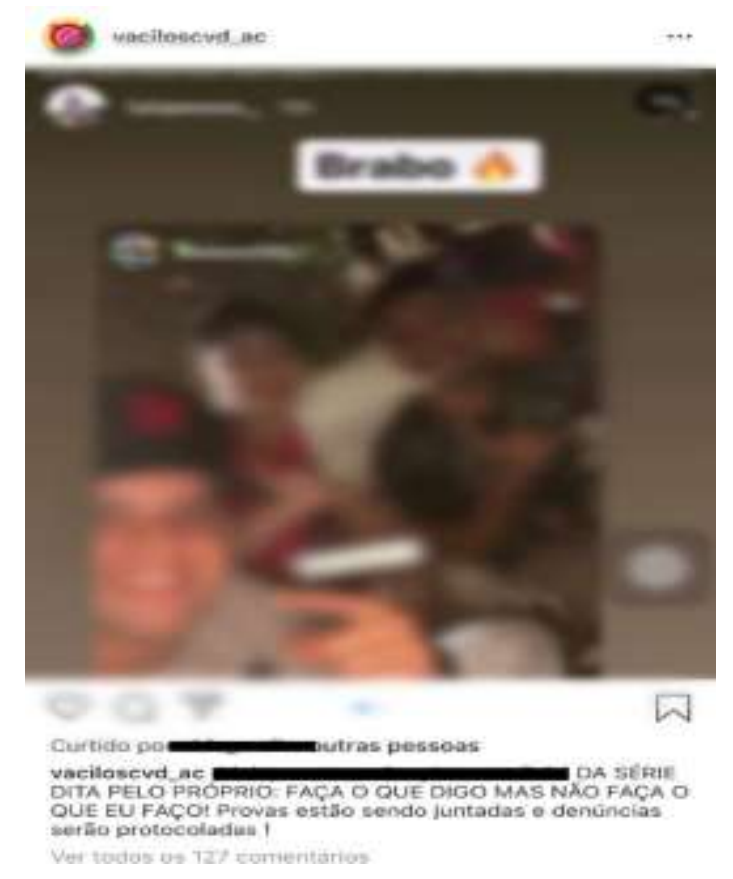

Fonte: Instagram @vaciloscvd_ac.

Trata-se de um print dos stories de um dos usuários expostos. $\mathrm{Na}$ imagem, três homens aparecem posando para a foto. $\mathrm{Na}$ legenda 
da postagem, o perfil marca os perfis dos indivíduos que aparecem nas imagens e escrevem a seguinte legenda: “da série dita pelo próprio: faça o que eu digo mas não faça o que eu faço! Provas estão sendo juntadas e denúncias serão protocoladas”.

Figura 6: foto postada pelo perfil @vaciloscvd_ac em 20 de abril de 2020.

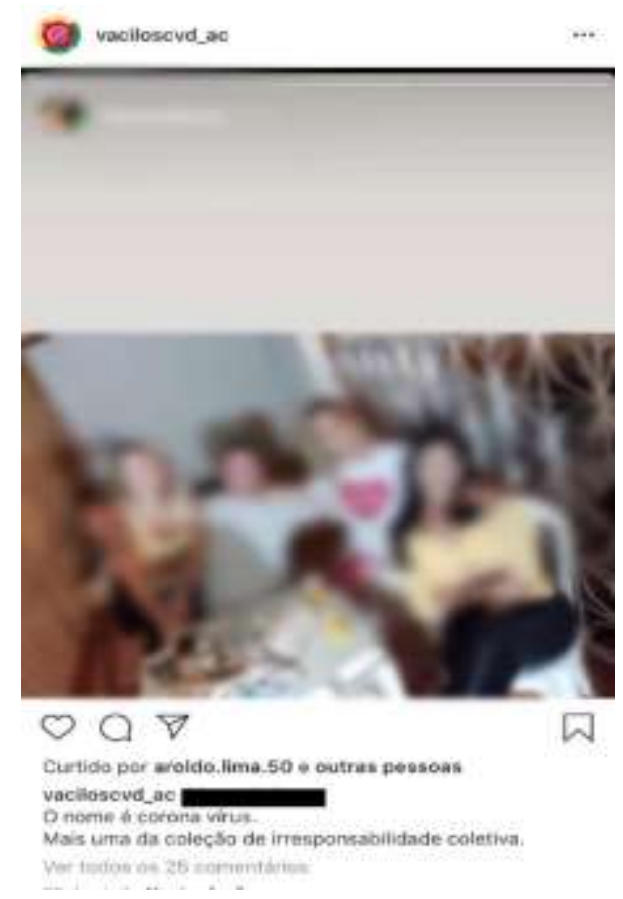

Fonte: Instagram @vaciloscvd_ac.

Trata-se de um print dos stories de um dos usuários expostos. $\mathrm{Na}$ imagem, quatro pessoas aparecem sentadas ao redor de uma mesa. Na legenda da foto, há a menção do perfil de uma das pessoas expostas, e os dizeres "o nome é corona vírus, mais uma da coleção de irresponsabilidade coletiva".

O terceiro perfil que será analisado, “@vacilocovidtimon” descreve em sua biografia que se trata de um "perfil criado para expor e para DENUNCIAR as pessoas de Timon e região que não estão cumprindo a quarentena", como se pode vislumbrar da Figura 7: 
Covid-19 E Perfis De "Denúncias" Na Quarentena": As Implicações Do Uso De...

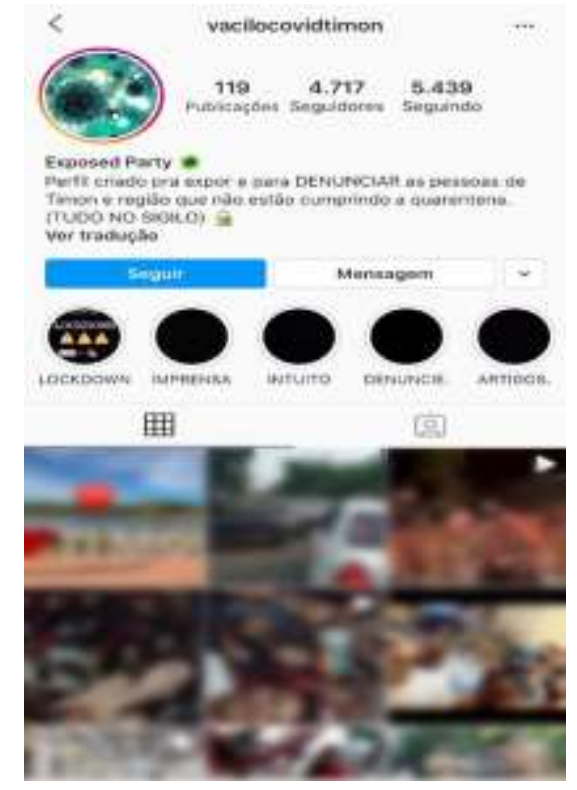

Fonte: Instagram @vacilocovidtimon.

Na data de acesso de 18 de agosto de 2020, o perfil contava com 4.717 mil seguidores e 119 publicações. De igual modo, há a menção clara do intuito do perfil: o de exposição e denunciação dos usuários que descumprem a quarentena. É o que se apresenta na Figura 8, abaixo:

Figura 8: foto postada pelo perfil @vacilocovidtimon em 13 de julho de 2020.

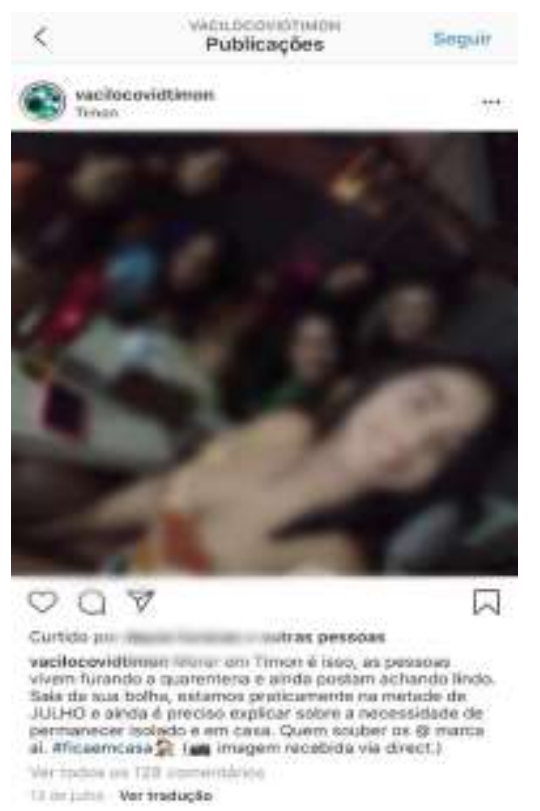

Fonte: Instagram @vacilocovidtimon. 
$\mathrm{Na}$ imagem, algumas mulheres aparecem sentadas em uma mesa com bebidas alcoólicas. Na legenda da foto foi escrito "Morar em Timon é isso, as pessoas vivem furando a quarentena e ainda postam achando lindo. Saia da sua bolha, estamos praticamente na metade de JULHO e ainda é preciso explicar sobre a necessidade de permanecer isolado em casa. Quem souber os @ marca aí. (imagem recebida via direct)".

Podem-se destacar duas coisas: o perfil pede para que marquem os perfis das mulheres que aparecem nas imagens, demonstrando o cunho expositivo. $\mathrm{E}$ ainda, que a imagem foi recebida por uma terceira pessoa que, sabendo do intuito do perfil, enviou a imagem, o que ressalta a proporção dos perfis exposeds. No mesmo sentido, a Figura 9:

Figura 9: foto postada pelo perfil @vacilocovidtimon em 31 de maio de 2020.

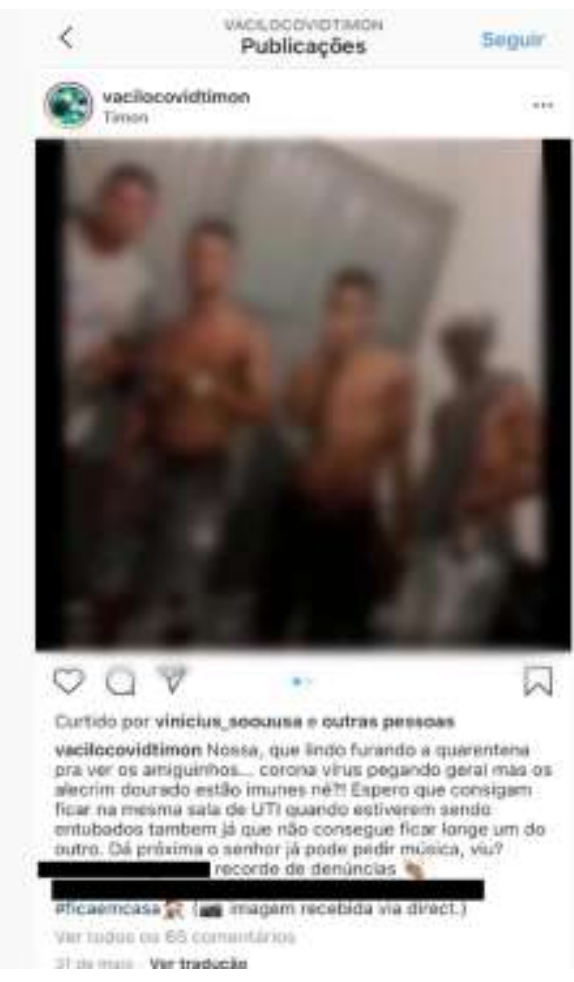

Fonte: Instagram @vacilocovidtimon.

$\mathrm{Na}$ imagem, quatro homens aparecem posando para a foto. Os indivíduos foram marcados na legenda que afirma o seguinte: "Nossa, que lindo furando a quarentena para ver os amiguinhos...corona vírus pegando geral mas os alecrim dourado estão imunes né? 
Covid-19 E Perfis De "Denúncias" Na Quarentena": As Implicações Do Uso De...

Espero que consigam ficar na mesma sala de UTI quando estiverem sendo entubados também já que não consegue ficar longe um do outro. Dá próxima o senhor já pode pedir música, viu? Recorde de denúncias". Dessa maneira, novamente demonstra-se o caráter repressivo do perfil, inclusive com menção do desejo de que os indivíduos sejam entubados juntos na UTI, havendo um juízo de valor da conduta dos usuários.

Pelo que se demonstrou, verifica-se que os referidos perfis estão publicando fotos pessoais retiradas dos perfis das pessoas expostas com o objetivo principal de "denunciar" publicamente o comportamento dessas pessoas que não estão cumprindo as medidas de isolamento social, publicizando essas imagens sem que, possivelmente, houvesse consentimento dos titulares para isso. Sendo assim, com base na exposição da estrutura da Internet e das redes sociais e após o recorte das publicações desses perfis em estudo, cabe analisar em que medida essas postagens causam violação ao direito à extimidade.

\section{DO DIREITO À PRIVACIDADE AO DIREITO À EXTIMIDADE: UMA ANÁLISE DA (IN) VIOLABILIDADE DO DIREITO À EXTIMIDADE FRENTE AOS CHAMADOS PERFIS “FURA QUARENTENA" NO INSTAGRAM}

A narrativa dos perfis criados no Instagram para divulgar e denunciar pessoas que estavam descumprindo a quarentena durante a pandemia do COVID-19, explorados no capítulo antecedente, fazem com que se discutam questões relativas ao direito à informação, bem como à privacidade e, no contexto do ciberespaço, de forma particular, à extimidade. Para o presente trabalho importa ingressar no campo da privacidade e extimidade. 
Não é difícil pensar em privacidade e em todos os direitos que existem para protegê-la na contemporaneidade. Contudo, o mesmo não ocorre se deslocarmos o referencial a outros momentos da história, especialmente porque a privacidade e a intimidade não são questões naturais ${ }^{6}$, mas sim criações da sociedade (BOLESINA, 2017, p. 22). Assim, a "privacidade é uma noção cultural induzida no curso do tempo por condicionantes sociais, políticas e econômicas, pelo que justifica proceder no plano histórico para sua contextualização jurídica" (DONEDA, 2006, p. 114)

Trazer o binômio público-privado à baila nesse momento é obrigatório para abordar o surgimento do direito à privacidade. Falar que a privacidade - e o direito que dele corresponde- não é natural, faz com que se possa afirmar que em um dado período as pessoas não possuíam a noção e tampouco tinham a privacidade materialmente existente em suas vidas. Dessa forma, questões que hoje são básicas quando se pensa na temática não existiam (MATTOS, 2015, p. 29).

Foi na Grécia e a partir do surgimento das pólis- cidade-estadoque houve a cisão em duas formas de vida, sendo uma a do lar e outra a da pólis, gerando essa distinção do público e privado. A esfera pública, segundo Arendt (2007, p. 37-40) era onde se desenvolvia a política e as liberdades. É nesse espaço que as pessoas apareciam para as demais e encontravam-se em busca de interesses comuns.

Já a esfera privada, como refere o nome usado, relacionava-se com a condição de privação em que eram submetidos os demais familiares, na medida em que somente os homens, chefes dos lares, estavam inseridos na esfera pública e eram atores dela (ARENDT, 2007, p. 40). Esse fenômeno também ocorreu com as sociedades

\footnotetext{
${ }^{6}$ Apesar de considerarmos a privacidade e a intimidade criações da sociedade, existem estudos que apontam o contrário, indicando que até mesmo os animais em certos momentos buscam a intimidade, sendo que com o homem isso não é diferente, de modo que há uma necessidade humana de em determinados momentos se estar só (FORTES, 2015, p. 95). Contudo, seguimos o entendimento de Hannah Arendt, que ao descrever o binômico público-privado dispõe enquanto construção humana. Assim, por mais que seja uma necessidade de animais não-humanos e humanos, há de se reconhecer que no que se refere a estes, houve um período em que não havia a distinção entre espaços públicos e privados, onde se desenvolvia a privacidade (AREDT, 2007, p. 44).
} 
Romanas e tanto nessas quantos nas sociedades gregas, a liberdade só existia na esfera pública (DONEDA, 2006, p. 123).

Percebe-se que nesse momento, a esfera privada estava diretamente ligada à família, enquanto a pública conectava-se com a política. Era dentro da casa e da família que se formava a concepção de privacidade.

Além da família, o trabalho humano teve um papel importante nessa mudança de paradigma, isso porque, primeiramente, o trabalho era desenvolvido na família, onde toda ou parte dela participava com o intuito de prover as suas necessidades. Esse labor era realizado no próprio espaço familiar, ou seja, no interior das propriedades e moradias (MATTOS, 2015, 30-31). Desse modo, não havia uma divisão entre espaços que eram destinados ao trabalho e outros destinados à família.

Acontece que, com a modernização e a introdução das indústrias, os homens começaram a exercer seus trabalhos fora das residências, fazendo com que surgisse uma divisão, onde de um lado estava a casa, destinada aos momentos familiares e amizades mais próximas e de outro lado, o trabalho, a política e demais relações sociais (MATTOS, 2015, p. 30-31; CANCELIER, 2017, p. 215).

Portanto, foi a partir do século XVIII, após o surgimento das referidas cidades que o espaço privado se edificou, tendo em vista que essa nova organização social fez com que a casa deixasse de ser um lugar misto, destinado tanto à família e ao trabalho, para ser o local destinado ao refúgio, ao particular e onde se permitia retirar as máscaras usadas no público (VAZ, 2015, p. 39; MATTOS, 2015, p. 31).

Posteriormente, há uma mudança no espaço público, que deixa de ter o foco no político e passa a ter no social (CANCELIER, 2017, p. 216). Nessa perspectiva, foi construída a noção de que determinados assuntos e questões precisariam ser mantidos no espaço privado, de modo a retirar do espaço público e social (BOLESINA, 2017, p. 230).

No que tange ao viés jurídico, há o reconhecimento da menção do direito à privacidade pela primeira vez no texto intitulado como 
“The right to privacy" de autoria de Samuel Warren e Louis Bandeis, no ano de $1890^{7}$. Nesse texto, consagrou-se a intimidade como o direito de estar só ou de ser deixado em paz. O objetivo dos autores era de "exigir a não perturbação da sua privacidade, impedindo a recolha de informações sobre a sua vida íntima ou a revelação de informações mesmo que estas fossem verdadeiras" (FARINHO, 2006, p. 44).

Percebe-se então, que os autores desse artigo citado, voltam a privacidade para a proteção da personalidade humana e não mais ligada às propriedades e locais físicos (CANCELIER, 2017, p. 217). A partir de então, o direito à privacidade foi se desenvolvendo e edificando, ainda que no mencionado texto não houvesse definição clara sobre o que se entende por privacidade (LEONARDI, 2012, p. 46). Até mesmo em razão disso, foram sendo criadas teorias e conceitos para melhor explicá-los. Uma das teorias criadas, refere-se as esferas concêntricas ou também denominada teoria das esferas de proteção, que dispõe que a proteção muda conforme a esfera que se atinge:

Seguindo, então, este critério de valoração, reconduzimos à esfera de publicidade todos os atos praticados em público pelo cidadão, cumulados com o desejo de que estes sejam efetivamente do conhecimento geral. Na esfera pessoal incluímos os atos praticados pelo indivíduo no seu ambiente social, sem que, no entanto, haja vontade na sua publicitação. Na esfera privada englobamos, já, as relações do indivíduo para com um número mais restrito de pessoas com quem tem uma maior proximidade emocional. Por último, assumimos a esfera íntima como sendo a mais sensível, envolvendo sentimentos intrínsecos à identidade do indivíduo e que apenas a ele dizem respeito (RAIMUNDO, 2012, p.13-14).

Alguns autores apontam que a teoria em questão é insuficiente para abranger as situações existentes que são de todo complexas, por isso foi de certo modo abandonada (BOLESINA, 2017, p 146-147).

\footnotetext{
7 Danilo Doneda refere em seu texto, que o texto citado não foi o ponto de partida da privacidade, de modo que esse marco deve ser relativizado. Apesar da ressalva do autor citado, será utilizado esse texto como referência do início jurídico da privacidade em razão de ser amplamente aceito como tal pela literatura que aborda a temática (DONEDA, 2006, p. 105).
} 
Além dessa questão, outra que deve ser considerada, no que diz respeito à série de termos que podem ser encontrados para falar sobre a privacidade, tais como vida privada, intimidade, segredo, reserva e etc.

Há também uma confusão e discordância por parte da doutrina no que tange aos significados e conceitos de direito à privacidade $\mathrm{e}$ direito à intimidade. Ademais, a literatura se divide ao tratar do direito à intimidade e à privacidade, de modo que para alguns, o primeiro termo refere-se ao gênero do qual decorrem espécies e onde estaria alocada a intimidade e para outros as palavras se referem a mesma proteção, sendo apenas sinônimos (LEONARDI, 2012, p. 51-53).

Inclusive, mesmo entre autores que diferem a privacidade da intimidade percebe-se uma desconexão no que tange aos conceitos apresentados. Para Gilmar Ferreira Mendes e Paulo Gustavo Gonet Branco (2015, p. 280) o direito à privacidade tem por “objeto os comportamentos e acontecimentos atinentes aos relacionamentos pessoais em geral, às relações comerciais e profissionais que o indivíduo não deseja que se espalhem ao conhecimento público" ao passo que o "objeto do direito a intimidade seriam as conversações e os episódios ainda mais íntimos, envolvendo relações familiares e amizades mais próximas".

Outros autores entendem que a privacidade está ligada com o direito de não haver invasão nas suas relações mais próximas e a segunda a questões mais íntimas como os sentimentos, ou seja, um direito ligado a subjetividade do indivíduo (WENDT,2015, p. 300).

Essa situação é comum em diversos países, não havendo uma consonância sequer em países que adotam o mesmo sistema jurídico common low ou civil low (LEONARDI, 2012, p. 49-50). No Brasil isso não é diferente. A Constituição Federal de 1988 prevê no art. $5^{\circ}$, inciso $\mathrm{X}$, a proteção da intimidade e da vida privada, porém, em momento algum, o texto utiliza o termo privacidade (BRASIL, 1988). O mesmo ocorre com o Código Civil (BRASIL, 2002). Percebe-se, entretanto, 
que o termo vida privada está inserido na privacidade, conforme a profusão dos termos abordado recentemente.

Apesar dessa constatação, importa trazer o entendimento de Doneda (2006, p. 110) sobre a presença no texto constitucional dos dois termos. Para o autor, decorre do fato de ser a primeira vez que esses direitos apareciam em sede de direitos fundamentais. Assim, dada a dificuldade de trato do tema já apresentado nas experiências internacionais, optou-se por adicionar ambos para não correr o risco de reduzir a abrangência da norma constitucional. Apesar disso, o autor considera mais razoável usar o termo privacidade, pois estabelece uma proteção suficiente e ainda possibilita a diferenciação de outros direitos fundamentais.

Tendo em vista todo esse cenário que permeia o conteúdo do direito à privacidade, para o presente trabalho será adotado o posicionamento de Bolesina (2017, p. 140), que trata a privacidade como sendo "o gênero que possui diversas manifestações a partir de si ou sob si"8.

Pode-se afirmar, que há ainda nos dias atuais uma concepção tradicional de privacidade, pois se entende que para estar protegido por ela seria necessário estar no âmbito das residências e outros locais seguros ou manter as questões que deseja na privacidade, escondidas das demais pessoas. Assim, imagens e tudo aquilo que for publicizado corre o risco de não ser amparado pelo direito, pois deixa o espaço privado para adentrar no público.

\footnotetext{
8 Posteriormente, o autor em comento, refere a necessidade de diferenciar a privacidade da intimidade, não para fins didáticos, mas para uma prevenção e reparação às violações desses direitos, o que faz através da lógica "quanto mais-tanto mais": "quanto mais a ameaça/violação a questões que orbitam a esfera de exclusividade de disposição informacional de uma pessoa, tanto mais deve ser os esforços para evitar/reparar a ameaça/dano. Portanto, em torno da privacidade, por exemplo, a violação às informações de uma situação de compra e venda de um veículo entre particulares não pode ser valorada igualmente a violação de uma situação envolvendo a condição sexual de uma pessoa. A segunda merece uma atenção mais austera em relação à primeira. Em assim sendo, ainda que no reconhecimento em si do direito ameaçado/lesado a distinção não faça tanta diferença, o mesmo não se pode dizer no que tange à prevenção e à reparação (que serão tanto mais incisivas, quanto mais aguda for a ameaça/violação)". (BOLESINA, 2017, p. 148).
} 
Isso é demonstrado em obra de Iuri Bolesina (2019, 4-5) que analisa alguns julgados atuais, onde a parte que teve seu direito violado não teve esse reconhecimento por estar em locais públicos ou por ser pessoa pública. Nessas decisões citadas pelo autor, foram utilizadas como fundamento uma decisão paradigmática, julgada em 2003, cujo fato ocorreu em 1994. O autor descreve esses julgados como decisões anacrônicas, pois situações atuais estão sendo julgadas tendo como base decisão que se deu há mais de uma década, em que muitas mudanças sociais e tecnológicas ainda não tinham ocorrido.

As alterações referidas acima, dizem respeito às revoluções tecnológicas e a criação da Internet que afetaram consideravelmente a sociedade, mudando a forma de se comunicar, relacionar, trabalhar, conforme já abordado no capítulo anterior. Todas essas mudanças devem ser levadas em conta pelo Direito, de modo que cabe uma adaptação do direito à privacidade, uma vez que ele é um direito maleável que deve se adequar às transformações da sociedade (DONEDA, 2006, p. 115). Nesse cenário de mudanças, destaca-se a visibilidade que hoje todos têm ou podem ter através da Internet, notadamente, do uso das redes sociais. (MASILI, 2018, p. 36).

As próprias ferramentas e ações possíveis na Internet e em especial, nas mídias e redes sociais, causam um estímulo a divulgação das informações íntimas e privadas dos usuários, fazendo com que essa exposição se tornasse cotidiana e naturalizada (CAMPOS; CARNEIRO; MAGALHÃES, 2020, p. 273). Assim, a divulgação de questões que se referem à privacidade e dados pessoais tornou-se uma realidade. Diante disso, "a intimidade agora é chamada a se mostrar, a aparecer diante do olhar dos outros, não mais se restringindo ao plano privado da casa, da família [...]” (MATTOS, 2015, p. 59).

Essa exposição massiva realizada no ciberespaço é apresentada também como consequência da sociedade do consumo, em que as pessoas se tornam mercadorias e, assim consideradas, precisam ser expostas e publicadas (VAZ, 2015, p. 26). 
Ademais, vive-se em uma sociedade de controle, marcada pela vigilância, aqui no que tange à dois modos: o panóptico $e$ o palinópitco, que advém de uma vigilância do Estado e dos particulares, respectivamente. Nesse último caso, todos estão vigiando e sendo vigiados ao mesmo tempo (BOLESINA, 2019, p. 193; BAUMAN, LYON, 2015, p 51).

Essa vigilância constante entre particulares é possibilitada em grande escala pelo uso das tecnologias, em especial pelo uso de celulares e câmeras, que possibilitam que se possa gravar e eternizar diversos momentos, sejam eles os mais importantes ou meros atos do cotidiano que, posteriormente, são lançados no ciberespaço (BOLESINA, 2019, p. 128-129). Sendo assim, percebe-se que a Internet possibilita que os usuários desse ciberespaço passem de meros receptores de conteúdo e informações para criadores e provedores deles também, fato já exposto no capítulo anterior. Portanto, toda a estrutura da internet e das redes sociais, se voltam para uma visibilidade antes não alcançada e vista (VAZ, 2015, p. 35).

A nova forma de expressão através da exposição e da visibilidade nas mídias, faz questionar a concepção de privacidade enquanto um direito de estar só, ligado a proteção dentro de espaços que não o público e que prevê apenas uma dimensão negativa. Isso porque com essa nova realidade não há como não levar em conta que os indivíduos se expõem, se relacionam e possuem nessa nova forma de relação uma maneira de construção de identidade e personalidade (MATTOS, 2015, p. 63).

Portanto, retirar a proteção do direito à privacidade devido à visibilidade alcançada, causa uma restrição à liberdade de todo indivíduo que tem direito de escolher o que fazer com sua imagem e sua intimidade, sem que com isso cause vulnerabilidade diante de ações de terceiros. É o que expõe Doneda ao fazer uma análise da necessidade de adequar a privacidade aos tempos atuais, onde se espera uma: 
ingerências externas, ganha hoje ainda mais em importância; passa a ser um pressuposto para que ela não seja submetida a formas de controle social que, em última análise, anulariam sua individualidade, cerceariam sua autonomia privada (para tocar em um conceito caro ao direito privado) e, em última análise, inviabilizariam o livre desenvolvimento de sua personalidade. A privacidade assume, portanto, posição de destaque na proteção da pessoa humana, não somente tomada como escudo contra o exterior- na lógica de exclusão- mas como elemento positivo, indutor da cidadania, da própria atividade política em sentido amplo e dos direitos de liberdade de uma forma geral (DONEDA, 2006, p. 142).

É nesse contexto, que surge à extimidade enquanto fenômeno e enquanto direito. A literatura aponta que o termo extimidade foi inaugurado pelo psicanalista Jacques Lacan, referindo-se às informações, conteúdos, sentimentos, que são internos dos indivíduos, mas que passam a ser exteriorizados a partir da sua vontade. (BOLESINA 2017, p. 187).

Assim, na concepção de Lacan, algumas questões não estavam adstritas somente a um espaço interno, que deveria estar protegido e não conhecido por terceiros, mas sim que questões particulares e internas do sujeito pudessem ser exteriorizadas, sem que com isso perdesse a sua condição de íntima e particular. Portanto, o sentido dado pelo autor em comento perpassa a limitação imposta pelo somente interior ou somente exterior fazendo, na verdade, com que esses dois limites se encontrem e construam um espaço de extimidade (ANTELO, 2009, p. 61).

É o que ocorre nas redes sociais, onde as pessoas passam a expor conteúdos que muitas vezes se referem a uma esfera de privacidade e intimidade, por razões de autoconhecimento, de afirmação, de construção e reformulação da identidade a partir do feedback do outro (BOLESINA 2017, p. 187).

A identidade na contemporaneidade também é formada por um binômio, em que de um lado aloca-se a identidade física e de outro a virtual, onde ambas são reais. A diferença é que última é mais complexa por se desenrolar no ciberespaço, onde surgem 
oportunidades e ações que não existem da mesma forma no espaço físico.

Sendo assim, percebe-se que a identidade virtual, por ser mais rica de possibilidades, acaba por atualizar a identidade física, uma vez que as ações, compartilhamentos, relacionamentos acabam por construí-la ou desconstruí-la. Isso porque, toda identidade é formada por dados de identificação, de feição subjetiva - opiniões, exposição-, de comportamento e de dados derivados (BOLESINA, 2017, p. 131-33).

Desse modo, a substituição do prefixo 'in' pelo 'ex' nos permite pensar em uma faceta exteriorizada da intimidade, marcando com isto a paradoxal condição que é falar de algo historicamente ligado ao "lá dentro", mas que agora sofre mutações e se manifesta no "lá fora" (MATTOS, 2015, p. 80). Seguindo o pensamento da autora, percebese que a extimidade se dá com a exposição de questões que até então deveriam ser restringidas aos olhos do público, mas que agora se encontram em um espaço de sociabilidade, que são as redes sociais e a Internet como um todo. Diz-se sociabilidade porque esse espaço não é público, tampouco privado, mas social, ou seja, perpassa entre essas duas dimensões.

Cabe destacar ainda que a extimidade não surge com a Internet, contudo, ela é intensificada por ela, tendo em vista que permite uma exposição contínua e em tempo real dos momentos da vida (CAMPOS; CARNEIRO; MAGALHÃES, 2020, p. 39-40).

Em razão disso, se faz necessário remodelar o direito à privacidade e à intimidade, acrescentando a dimensão ativa dele. Somente assim será possível falar nesses direitos na contemporaneidade, caso contrário estar-se-á somente frente a um dever de intimidade, dever esse que dita que somente será possível ter sua tutela aquele que manter-se longe dos espaços públicos e da visibilidade que hoje o ciberespaço proporciona a todos (BOLESINA, 2019, p. 8-10). Esse acréscimo da dimensão positiva é abordado pelo autor em comento como sendo o primeiro pressuposto do direito à extimidade (BOLESINA, 2017, p. 210). 
No que tange ao segundo pressuposto, Bolesina destaca que para pensar no direito à extimidade é preciso recorrer ao direito à liberdade de expressão, isso porque aquele depende de "uma liberdade de expressão essencialmente democrática que tutele de modo amplo e crítico tanto o direito de manifestação, quanto os excessos/abusos na manifestação, bem como os usos dessa manifestação por terceiros" (BOLESINA, 2017, p. 221).

O terceiro e último pressuposto apresentado por Bolesina refere-se à transformação da dicotomia público-privado, pois segundo sustenta, a extimidade é a intimidade que vai ser exposta em uma esfera que não é privada nem pública e sim marcada pela sociabilidade, a qual é uma mistura de ambas.

A partir desses três pressupostos, chega-se ao direito à extimidade, como sendo:

[...] o direto que se tem de usufruir propositivamente da intimidade, por meio da sua exposição voluntária, sem a intenção consciente de tornar a informação veiculada pública, em face de terceiros ou/e/ em ambientes de sociabilidade (que reúnem e mesclam o público e o privado)-tradicionalemnte entendidos como públicos e que contextualmente demonstre o intento de autoconhecer-se, autoaceitar-se, empoderar-se e/ou autorealizar-se, enfim, emancipar-se com autoestima, autonomia e responsabilidade, valendo-se do outro (BOLESINA, 2017, p, 237).

Além dos pressupostos anteriormente tratados, o autor usado como base para falar de direito à extimidade apresenta três requisitos para estar-se diante desse direito.

O primeiro deles refere que o conteúdo que foi exteriorizado diga respeito a intimidade pessoal, tendo em vista que há um descolamento da tutela da privacidade que antes se fixava no local para a proteção pessoal. O segundo requisito, consiste na necessidade de que a exposição seja voluntária, o que de imediato leva a excluir aquelas feitas por terceiros. E por fim, o terceiro requisito condiciona a extimidade à externalidade que tenha tido como intuito a emancipação pessoal, visto que tal direito é inteiramente ligado a construção da identidade. 
Esses requisitos serão retomados a seguir para analisar as postagens realizadas pelo perfil exposto no capítulo antecedente.

A partir do conceito construído pelo autor, entende-se que as informações que são expostas nas redes sociais não se tornam públicas, o que impede que outras pessoas possam utilizá-la, dado que elas são êxtimas e foram lançadas em um espaço de sociabilidade. É claro que, para isso, é necessário cumprir com os requisitos apresentados acima.

Sendo assim, o conteúdo que se torna êxtimo continua pertencendo à esfera do indivíduo titular, o qual possui o poder de decidir se, como e quando isso pode ser usado por terceiros, através do direito à autodeterminação informativa. Portanto, o sujeito tem o direito e deve ter poderes para controlar informações e dados que se referem a ele (RAIMUNDO 2012, p. 10).

Diante disso, retorna-se ao caso dos perfis do Instagram analisados para verificar em que medida as imagens republicadas nele derivam de uma extimidade e por isso estariam sob o amparo do direito em estudo. Para isso, é necessário preencher os requisitos, ou seja, que o conteúdo publicado seja um dado pessoal, exposto voluntariamente e não seja apenas um mero exibicionismo, mas tenha como propósito a reafirmação e/ou transformação do sujeito a partir do olhar do outro.

As figuras de número 1, 4 e 7, referem-se aos perfis dos Instagrans “@furaquarentena”, “@vaciloscvd_ac” e “@vacilovidtimon”, os quais contam com o número de 896 seguidores, 11,7 mil seguidores e 4, 717 mil seguidores, respectivamente. Percebese que o número de todos os perfis é significativo. Além do fato de que é um perfil público, onde qualquer pessoa pode ter acesso, sendo ou não seguidor dele. Desse modo, as publicações contidas nele podem alcançar um número ainda maior de pessoas que o seu número de seguidores, o que acaba por gerar uma exposição maior no que tange às informações e dados das pessoas que foram ali expostas.

Ademais, esses são apenas três perfis de inúmeros que existem ativos na rede social Instagram, demonstrando, assim, que têm sido 
criados de forma massiva durante a atual situação de pandemia do COVID-19. Portanto, são fatos dignos do olhar jurídico.

No que tange às demais postagens (números 5,6,8,9), será feita uma análise conjunta delas para evitar repetição.

Cabe referir desde já que todas as imagens selecionadas- não diferente das demais existentes nos perfis-, são muito semelhantes. São fotos que retratam a divisão de um momento da vida privada com outras pessoas, que igualmente aparecem na mesma, conforme é possível observar no capítulo anterior. Assim, elas mostram pessoas sentadas, em pé, abraçadas, em um ambiente mais restrito ou em um ambiente mais comemorativo (como na foto do chá de bebê), mas que a sua estrutura geral é basicamente a mesma. É a mesma porque são pessoas que estão voluntariamente (primeiro requisito) expondo na sua rede social Instagram a sua imagem, que corresponde a um momento de intimidade (segundo requisito) e com o objetivo de construir e transformar a identidade virtual e consequentemente, a identidade física (terceiro requisito).

Assim, conforme já demonstrando anteriormente, as pessoas estão dispostas a dividir a sua intimidade com o outro, em troca de autoconfirmação, autorealização, autoestima, transformação da identidade, tudo isso a partir das respostas do outro. As próprias ferramentas disponíveis nas redes sociais permitem essa troca entre aquele que posta e aquele que reage, seja através de curtidas, comentários, compartilhamentos, reações, atitudes que a rede social coloca à disposição do usuário para que ele possa interagir e dar a sua análise no que é postado pelo outro.

Sendo assim, pode-se considerar que as fotos originariamente postadas pelos usuários do Instagram e repostadas pelos três perfis que tinham como propósito "denunciar" pessoas que furam a quarentena, tratam de momentos de extimidade, onde o sujeito lança ao social momentos da esfera íntima. Por isso, surge nesses fatos o direito à extimidade, que protege o titular de atitudes de terceiros que 
violem seus direitos fundamentais, inclusive quando ele mesmo voluntariamente expõe o conteúdo.

É em razão disso, que o autor Iuri Bolezina (2017, p.196) expõe que o que se almeja é ter um direito de intimidade negativo, mas também positivo, que seja capaz de tutelar o sujeito diante do uso ilícito da sua intimidade, que estava interna por vontade do titular, mas que consiga tutelar igualmente o que foi exposto de acordo com a vontade do titular.

Portanto, resta claro que o uso das imagens pelos três perfis "denunciantes" acabam por violar o direito à imagem, uma vez que possivelmente, não receberam autorização para tanto, que é necessária, inclusive, de todos os presentes na imagem. Além do mais, as postagens estão acompanhadas de legendas de cunho depreciativo, vexatório e humilhantes. Assim, o objetivo desses perfis é causar constrangimento às pessoas e realizar uma denúncia em um ambiente que não é oficial e destinado a isso.

Outro elemento importante de ser destacado, refere-se às consequências desse uso indiscriminado para os titulares, que ficam verdadeiramente expostos para um número indeterminado de pessoas, estando ainda aliados às referidas legendas que causam constrangimento e ainda podem gerar um linchamento virtual nas redes.

Portanto, é preciso que o direito à extimidade seja reconhecido e capaz de surtir efeitos a fim de proteger os dados pessoais daqueles que, se valendo de um direito, expõem sua intimidade voluntariamente, mas que, posteriormente, são lesados pelo uso ilícito por terceiros e que acabam por sofrer danos e violações de direitos fundamentais. Por isso, cabe ao titular determinar o acesso, o uso ou não delas, com base no princípio da autodeterminação informativa (RAIMUNDO, p. 10). É nesse sentido que o autor Iuri Bolesina (2017, p. 244) conclui que o direito à proteção de dados é um instrumento de proteção ao direito à extimidade. 


\section{CONCLUSÃ̃o}

A sociedade contemporânea se transformou no que Castells denomina como sociedade em rede, que é caracterizada pela sua predominante forma de organização, com um sistema de nós interligados, operada por tecnologias da comunicação e da informação. Dessa forma, o ciberespaço configura-se como o lugar em que as interações ocorrem dentro da sociedade em rede, proporcionando a interação dos usuários, com transmissão desses conteúdos e informações. Em contrapartida, a Internet é a máquina propulsora da sociedade em rede, pois representa a infraestrutura física das telecomunicações da rede mundial de computadores.

Nesse sentido, os usuários inseridos nessa sociedade em rede se tornam os principais produtores e receptores de conteúdo e informação, moldando-se à Rede e também a modificando, determinando os conteúdos que desejam consumir, havendo uma supervalorização de outras formas de interatividade, como ocorre com as redes sociais.

Essas questões acabam por delinear determinados comportamentos atuais, como ocorre com a tendência da exposição e da visibilidade que há nas redes sociais, onde as pessoas voluntariamente optam por dividir com os demais momentos da sua vida privada. Frisa-se que esse comportamento de compartilhar momentos da rotina e da intimidade tem sido cada vez mais comum nos dias atuais.

Diante de toda essa visibilidade proporcionada pela Internet e em especial pelas redes sociais, cabe uma reformulação da noção atribuída ao direito à privacidade, que tradicionalmente é um direito negativo-defensivo e que por isso acaba por surtir efeitos apenas diante de uma violação, quando o titular estará sendo tutelado desde que ele não seja responsável pela exposição do conteúdo usado por terceiro. Percebe-se que é contraditório viver em uma época em que a 
exposição é um comportamento comum e até mesmo incentivado pelas próprias redes sociais e não estar protegido juridicamente ao mesmo tempo.

É preciso, então, afirmar o direito à extimidade enquanto um direito que tem como intenção estabelecer uma dimensão ativa/positiva, que existe para dar a possibilidade de as pessoas exporem questões da intimidade, se assim desejarem, em um ambiente de sociabilidade e mesmo assim permanecer com o respaldo jurídico em face de atitudes de terceiros que passem a usar de tais informações sem o consentimento devido.

Para receber a devida proteção e estar enquadrado no direito à extimidade é preciso preencher três requisitos, que são: a) se referir a um dado da intimidade pessoal; b) que foi voluntariamente exposto pelo titular e por fim, c) que tenha a intenção a construção da identidade pessoal, através do retorno do outro.

Portanto, o direito à extimidade vai ao encontro do comportamento atual de estar sempre visível no ciberespaço. Foi justamente esse comportamento que proporcionou o uso das imagens pelos perfis de Instagram que desejavam "denunciar" quem estivesse quebrando as regras de quarentena. Acontece que o fato da pessoa publicar uma foto em uma rede social, compartilhando um momento da intimidade, não faz com que essa foto se torne pública e possa ser utilizada pelos demais usuários, sem respeitar direitos fundamentais.

Além do mais, conforme o entendimento de Iuri Bolesina, adotado no decorrer do texto, as redes sociais são um ambiente de sociabilidade, onde ocorre uma mistura entre espaço público e privado, formando um espaço social. Logo, os dados expostos nesse ambiente não são públicos, mas social.

Sendo assim, as postagens feitas pelos perfis analisados ferem o direito à extimidade dos usuários da rede social Instagram, na medida em que usam uma imagem, que foi originariamente postada em um momento de extimidade, sem o consentimento dos titulares.

Há ainda que destacar que nos casos das publicações verificadas é clara a intenção dos administradores dos perfis de constranger e 
Covid-19 E Perfis De "Denúncias" Na Quarentena": As Implicações Do Uso De...

humilhar as pessoas que constam na foto publicada. Esse constrangimento é gerado pelo fato de ser exposto em um perfil que se intitula "denunciante" de pessoas que quebram as regras do isolamento social, corroborado ainda, por legendas que agridem e humilham as pessoas expostas.

A situação da pandemia vivenciada pelo COVID-19 não deve justificar a ofensa a direitos fundamentais, notadamente, ao direito à extimidade, essencialmente porque existem espaços oficiais da Administração Pública aptos a receber e realizar a verificação das denúncias.

Data de Submissão: 31/07/2020

Data de Aprovação: 05/12/2020

Processo de Avaliação: double blind peer review

Editor Geral: Jailton Macena de Araújo

Editor de Área: Fernando Joaquim Ferreira Maia

Assistente Editorial: Tâmisa Rúbia Santos Do Nascimento Silva

\section{REFERÊNCIAS}

ARENDT, Hannah. A Condição Humana. $10^{\text {a }}$ ed. Rio de Janeiro: Forense Universitária. 2007.

ANTELO, Raul. Subjetividade, extimidade. Boletim de Pesquisa NELIC v. 9, $\mathrm{n}^{\mathrm{O}}$ 14. 2009.2. Disponível em:

https://periodicos.ufsc.br/index.php/nelic/article/view/1984784X.2009v9n14p66/11638. Acesso em: 17.ago.2020.

BAUMAN, Zygmunt; LYON, David. Vigilância líquida. Ciudad Autónoma de Buenos Aires: Paidós, 2015.

BOLESINA, Iuri. O direito à extimidade: as inter-relações entre identidade, ciberespaço e privacidade. $1^{\mathrm{a}}$ ed. Florianópolis: Empório do Direito. 2017.

BOLESINA, Iuri. Responsabilidade Civil por violação do direito à extimidade. In: $5^{\circ}$ Congresso Internacional de Direito e contemporaneidade. Universidade Federal de Santa Maria. 2019, 
Santa Maria. Anais... Santa Maria. Santa Maria: Brasil. 2019. Disponível em: https://www.ufsm.br/cursos/pos-graduacao/santamaria/ppgd/wp-content/uploads/sites/563/2019/o9/5.7.pdf. Acesso em: 15.jun.2020.

BRASIL, Constituição da República Federativa do Brasil. Diário oficial da República Federativa do Brasil, Brasília, DF. 14 fev.2000. Disponível em:

http://www.planalto.gov.br/ccivil_03/Constituicao/Constituicao.ht m. Acesso em: 18. jun.2020

CAMPOS, Carolina Mendes; CARNEIRO, Terezinha Feres.

MAGALHÃES, Andrea Seixas. Extimidade virtual e conjugalidade: possíveis repercussões. Revista Psicologia: teoria e prática. v. 22, n. 1, 2020. Disponível em:

http://editorarevistas.mackenzie.br/index.php/ptp/article/view/116 38. Acesso em: 16.jun.2020.

CANCELIER, Mikhail Vieira de Lorenzi. O direito à privacidade: perspectiva histórica e o cenário brasileiro. Seqüência: estudos jurídicos e políticos. Florianópolis. n. 76, p. 213-240, ago. 2017. p. 213-240. Disponível em:

https://dialnet.unirioja.es/servlet/articulo?codigo=6124470. Acesso em: 15.jun.2020.

CARDOSO, Gustavo. A mídia na sociedade em rede: filtros, vitrines, notícias. Rio de Janeiro: Editora FGV, 2007.

CASCELLA, Marco; RAJNIK, Michael; CUOMO, Arturo; DULEBOHN, Scott; DI NAPOLI, Rafaella. Features, Evaluation and Treatment Coronavirus (COVID-19). Tradução livre pelas autoras. Ilha do Tesouro, FL: StalPearls, 2020. Disponível em: https://www.ncbi.nlm.nih.gov/books/NBK554776/. Acesso em: 24 de junho de 2020.

CASTELLS, Manuel. A Sociedade em Rede. tradução Roneide Venacio Majer, atualização para a $6^{\mathrm{a}}$ edição, São Paulo: Paz e Terra, 1999.

CASTELLS, Manuel. A galáxia da internet: reflexões sobre a internet: reflexões sobre a internet, os negócios e a sociedade. Traduzido por Maria Luiza X. de A. Borges, revisão Paulo Vaz. Rio de Janeiro, RJ: Editora Zahar, 2003.

CASTELLS, Manuel; CARDOSO, Gustavo. A Sociedade em Rede do Conhecimento à Acção Política. Belém: Imprensa Nacional Casa da Moeda, 2005.

CASTELLS, Manuel. O poder da Comunicação. Lisboa: Fundação Caloust Gulbenkian, 2013. 
Covid-19 E Perfis De "Denúncias" Na Quarentena": As Implicações Do Uso De...

DONEDA, Danilo. Da privacidade à proteção de dados

pessoais. Rio de Janeiro: Renovar. 2006.

FARINHO, Domingos Soares. Intimidade da vida privada e media no ciberespaço. Coimbra: Almedina, 2006.

GARCIA MARQUES; LOURENÇO MARTINS. Direito da Informática. Almedina, Coimbra, 2000.

INSTAGRAM. @furaquarentena8. 2020. Disponível em: https://www.instagram.com/furaquarentena8/?hl=pt-br. Acesso em: 28 jun.2020.

INSTAGRAM. @furaquarentena8. Enquanto os irresponsáveis continuarem comemorando, os leitos de UTI continuarão lotado e os casos continuarão aumentando. 2020. Disponível em:

https://www.instagram.com/p/CBsosasB56S/. Acesso em: 27 jun. 2020.

INSTAGRAM. @furaquarentena8. Povo de São Benedito continua agindo errado e os casos aumentando. 2020. Disponível em: https://www.instagram.com/p/CBtpZecBPw6/. Acesso em: 27 jun.2020.

INSTAGRAM. @vaciloscvd_ac. Disponível em: https://www.instagram.com/vaciloscvd ac/. Acesso em: 18 ago. 2020.

INSTAGRAM. @vaciloscvd_ac. DA SÉRIE DITA PELO PRÓPRIO: FAÇA O QUE DIGO MAS NÃO FAÇA O QUE EU FAÇO! Provas estão sendo juntadas e denúncias serão protocoladas. Disponível em: https://www.instagram.com/p/B of $3 \mathrm{BESe} /$. Acesso em: 18 ago. 2020.

INSTAGRAM. @vacilosevd_ac. O nome é corona vírus. Mais uma da coleção de irresponsabilidade coletiva. Disponível em: https://www.instagram.com/p/B NlBoVBMLm/. Acesso em: 18 ago. 2020.

INSTAGRAM. @vacilocovidtimon. 2020. Disponível em: https://www.instagram.com/vacilocovidtimon/. Acesso em: 18 ago. 2020.

INSTAGRAM. @vacilocovidtimon. Morar em Timon é isso, as pessoas vivem furando a quarentena e ainda postam achando lindo. Saia da sua bolha, estamos praticamente na metade de JULHO e ainda é preciso explicar sobre a necessidade de permanecer isolado e em casa. Quem souber os @ marca aí. \#ficaemcasa (imagem recebida 
via direct.). Disponível em: https://www.instagram.com/p/CClXQb$\mathrm{H} \mathrm{O} /$. Acesso em: 18 ago. 2020.

INSTAGRAM. @vacilocovidtimon. Nossa, que lindo furando a quarentena pra ver os amiguinhos... corona vírus pegando geral mas os alecrim dourado estão imunes né?! Espero que consigam ficar na mesma sala de UTI quando estiverem sendo entubados tambem já que não consegue ficar longe um do outro. Dá próxima o senhor já pode pedir música, viu? @flauberty gom3s recorde de denúncias@jheyson saantos @m4rkoos @paulohenryquebdl \#fica emcasa ( imagem recebida via direct.). Disponível em: https://www.instagram.com/p/CA2sHfEHgXq/. Acesso em: 18 ago. 2020.

LAVADO, Thiago. Isolamento por coronavírus muda padrão de consumo da internet no Brasil. Portal de notícias G1, 19/03/2020, Seção: tecnologia. Disponível em:

https://g1.globo.com/economia/tecnologia/noticia/2020/03/19/isol amento-por-coronavirus-muda-padrao-de-consumo-da-internet-nobrasil.ghtml. Acesso em: 27 jun. 2020.

LEONARDI, Marcel. Tutela e privacidade na Internet. São Paulo: Saraiva, 2012.

LÉVY, Pierre. Cibercultura. Traduzido por Carlos Irineu da Costa. São Paulo: Ed. 34, 1999, 2. ed, 2000.

MAPEAMENTO mostra aumento do consumo de mídia online no Brasil durante a quarentena. Portal de notícias G1, 16/04/2020, Seção: mídia e marketing. Disponível em: https://g1.globo.com/economia/midia-emarketing/noticia/2020/04/16/mapeamento-mostra-aumentaconsumo-de-midia-online-no-brasil-durante-a-quarentena.ghtml. Acesso em: 27 jun. 2020.

MASILI, Clarissa Menezes Vaz. Regulação do uso de dados pessoais no Brasil: papel do usuário na defesa de um direito à tutela de dados pessoais autônomo. 2018. 197f. Dissertação (mestrado em direito). Faculdade de Direito da Universidade de Brasília. Brasília. 2018. Disponível em: https://repositorio.unb.br/bitstream/10482/34290/3/2018 Clariss aMenezesVazMasili.pdf. Acesso em:16.jun.2020.

MATTOS, Carolina Mendes Campos Oliveira; FERÉS, Carneiro, Terezinha (Orientadora). Extimidade virtual na conjugalidade: um estudo sartriano sobre a nova perspectiva da intimidade. Rio de Janeiro, 2015. 187p. Tese de Doutorado - Departamento de Psicologia, Pontifícia Universidade Católica do Rio de Janeiro. Disponível em: https://www.maxwell.vrac.puc- 
Covid-19 E Perfis De "Denúncias" Na Quarentena": As Implicações Do Uso De...

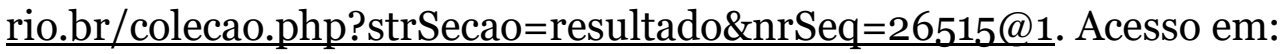
15.jun.2020.

MENDES, Gilmar Ferreira; BRANCO, Paulo Gustavo Gonet. Curso de Direito Constitucional. $10^{\mathrm{a}}$ ed. ver. atual. São Paulo: Saraiva, 2015 .

RAIMUNDO, João Pedro Sargaço Dias. Uma nova frente da proteção de dados pessoais: a (im)possibilidade de assegurar um eventual direito ao esquecimento. Dissertação de Mestrado em Direito. Faculdade de Direito. Universidade do Porto. Disponível em: https://repositorioaberto.up.pt/bitstream/10216/75966/2/12211.pdf. Acesso em: 04.abr.2020.

RAMOS, Gisele; LANZA, Luíza. Perfil que denuncia "furos" na quarentena atinge 50 mil seguidores. Portal $\mathrm{R} 7$, Minas Gerais, 17/04/2020. Seção: Coronavírus. Disponível em:

https://noticias.r7.com/minas-gerais/perfil-que-denuncia-furos-naquarentena-atinge-50-mil-seguidores-17042020. Acesso em: 28 jun. 2020.

RECUERO, Raquel. Redes Sociais na internet. Porto Alegre: Sulina, 2009.

VAZ, Mairê de Miranda Oliveira. Extimidade e o imperativo da visibilidade mediática na cibercultura. 2015. 66f. Dissertação (mestrado em comunicação). Universidade Paulista, São Paulo, SP. 2015. Disponível em: http://repositorio.unip.br/programa-de-posgraduacao-stricto-sensu-em-comunicacao/extimidade-e-oimperativo-da-visibilidade-mediatica-na-cibercultura/. Acesso em: 17.jun.2020

WENT, Emerson. Internet: percepções e limites em face do direito à extimidade na rede. Revista Jurídica Luso-Brasileira. Ano 1. $\mathrm{n}^{\mathrm{o}}$ 6. 2015. Disponível em: http://www.cidp.pt/revistas/rjlb/2015/6/2015 06 o000 Capa.pdf. Acesso em: 23.jun.2020. 


\title{
Covid-19 And Profiles Of "Complaints" In Quarentine: The Implications Of Using Personal Data To Expose Those Who Breach The Social Isolation Rules And The (In) Violability Of The Right To Extimity
}

\author{
Eduarda Aparecida Santos Golart
}

\author{
Gabriela Gonçalves de Medeiros
}

Isabel Christine Silva De Gregori

\begin{abstract}
At the same time, there is a culture of visibility in which day-to-day and private life issues are voluntarily exposed on social networks. In view of this, the right to extinction emerges as the prerogative that the holder has to expose intimacy in sociability means - such as social networks - and yet have the possibility of being protected against acts of third parties. As a result, it is important to check the creation of profiles on the Instagram social network to "denounce" people who fail to comply with the social isolation measures imposed as a result of COVID-19, through the publication of images taken from the profiles of the owners of the published images. In view of these facts, the problem presented in this paper is the extent to which the use of personal data published in Instagram profiles intended to "denounce" anyone who fails to comply with the rules of social isolation in times of COVID-19 generates a violation of the right to extinction? To answer the problem, the inductive method is used as the approach method, the bibliographic analysis as a method of procedure and, finally, the use of files and abstracts as a research technique. Thus, it is concluded that there is a violation of the right to extinction in the cases under analysis, because despite the photos have been posted on the social network Instagram, this does not make them public domain nor does it authorize their indiscriminate use by third parties.
\end{abstract}

Keywords: COVID-19. Right to extinction. Network society.

DOI: https://doi.org/10.22478/ufpb.1678-2593.2020v19n42.54299

Conteúdo sob licença Creative Commons: Attribuition-NonCommercial-NoDerivative 4.o International (CC BY-NC-ND 4.0) 